\title{
Pengaruh perbedaan rasio menir kedelai proteksi dan tanpa proteksi terhadap konsumsi, kecernaan dan nilai nutrien pakan Domba Ekor Gemuk
}

\author{
Joko Riyanto *, Susi Dwi Widyawati, Sudibya \\ Program Studi Peternakan, Fakultas Pertanian, Universitas Sebelas Maret, Surakarta, 57126 \\ *Correspondence: jokoriyanto@staff.uns.ac.id
}

Received: January 12 ${ }^{\text {th }}, 2020$; Accepted: September 11th, 2020 ; Published online: November $26^{\text {th }}, 2020$

\begin{abstract}
Abstrak
Tujuan: Penelitian ini bertujuan untuk menguji pakan penggemukan Domba Ekor Gemuk (DEG) ditinjau dari aspek konsumsi, kecernaan dan efisiensi penggunaan nutrien.

Metode: Pakan penelitian menggunakan konsentrat mengandung menir kedelai tanpa proteksi dan terproteksi menggunakan formaldehid kadar 37\%. Domba penelitian sebanyak 15 ekor dibagi dalam tiga macam perlakuan masing-masing perlakuan diulang satu kali menggunakan satu ekor DEG setiap ulangan. Perlakuan terdiri dari $\mathrm{P} 1=30 \%$ rumput gajah $(\mathrm{RG})+55 \%$ konsentrat basal $(\mathrm{KB})+10 \%$ menir kedelai tanpa terproteksi (MKTP) $+5 \%$ menir kedelai proteksi (MKP), P2 $=30 \%$ rumput gajah $(\mathrm{RG})+55 \%$ konsentrat basal $(\mathrm{KB})+7.5 \%$ menir kedelai tanpa terproteksi (MKTP) $+7.5 \%$ menir kedelai proteksi $(\mathrm{MKP})$, dan $\mathrm{P} 3=30 \%$ rumput gajah $(\mathrm{KB})+55 \%$ konsentrat basal $(\mathrm{KB})+5 \%$ menir kedelai tanpa terproteksi (MKTP) $+10 \%$ menir kedelai proteksi (MKP). Parameter meliputi konsumsi, kecernaan dan efisiensi penggunaan nutrien bahan kering, bahan organik dan protein kasar.

Hasil: Hasil penelitian menunjukan bahwa perbedaan perlakuan berpengaruh nyata terhadap konsumi, kecernaan dan protein kasar dapat dicerna $(\mathrm{P}>0,05)$ dan tidak berpengaruh terhadap konsumsi dan kecernaan bahan kering dan bahan organik serta bahan kering dan bahan organik tercerna $(\mathrm{P}<0,05)$. Kecernaan protein kasar P1, $\mathrm{P} 2$ dan $\mathrm{P} 3$ berturut-turut 72,33\%, 75,17\%, dan 77,13\%. Kesimpulan: Pakan P3 untuk penggemukan DEG dihasilkan konsumsi dan kecernaan protein kasar yang lebih tinggi dan efisien dari pada P1.
\end{abstract}

Kata Kunci: Menir Kedelai; Proteksi; Konsumsi; Kecernaan; Nilai Nutrien; Domba Ekor Gemuk

Abstract

Objective: This study aimed to observe the fat tailed sheep feed fattening in terms of consumption, digestibility and efficient use of nutrients.

Methods: Research feeds using concentrates containing soybean groats with and without protection using formaldehyde at $37 \%$. Fifteen fat tailed sheep were used in this experiment that divided into three different treatments, each treatment was repeated once using one DEG each repetition. The treatment consisted of $\mathrm{P} 1=30 \%$ elephant grass $(\mathrm{EG})+55 \%$ basal concentrate $(\mathrm{CB})+10 \%$ unprotected soybean groats (USG) $+5 \%$ protected soybean groats (PSG), $\mathrm{P} 2=30 \%$ elephant grass $(\mathrm{EG})+55 \%$ basal concentrate $(\mathrm{BC})+7.5 \%$ unprotected soybean groats (USG) $+7.5 \%$ protected soybean groats (PSG), and $\mathrm{P} 3=30 \%$ elephant grass $(\mathrm{EG})+55 \%$ basal concentrate $(\mathrm{BC})+5 \%$ unprotected soybean groats 
(USG) $+10 \%$ protected soybean groats (PSG). The parameters observed were feed intake, digestibility and efficient use of dry matter, organic matter and crude protein.

Results: The results showed that differences in treatment significantly affected feed intake, and digestibility of crude protein $(\mathrm{P}>0.05)$ and did not affect the feed intake and digestibility of dry matter and organic matter as well as digested dry matter and organic matter $(\mathrm{P}<0.05)$.

Conclusions: The digestibility of crude protein P1, P2 and P3 were 72.33\%, 75.17\%, and 77.13\%, respectively. P3 for fattening DEG feed intake and digestibility generated a higher crude protein and more efficient than P1.

Keywords: Soybean groats; Protection; Consumption; Digestion; Nutrient Value; Fat Tailed Sheep

\section{PENDAHULUAN}

Domba Ekor Gemuk (DEG) merupakan salah satu ternak domba lokal di Indonesia yang banyak dipelihara oleh peternak baik dalam skala rumah tangga maupun usaha peternakan komersial. Usaha peternakan Domba di Indonesia sebagian besar merupakan usaha peternakan rakyat. Sebagian besar domba yang dipelihara oleh peternak adalah bangsa DEG yang mudah dipelihara dan beradaptasi dengan lingkungan [1]. Namun demikian produktivitasnya masih rendah, sehingga perlu upaya penggunaan pakan yang tepat dan efisien.

Menir kedelai merupakan salah satu bahan pakan mengandung protein diatas 35\% dan sudah dapat digunakan sebagai bahan pakan sapi potong, domba ekor tipis dan domba ekor gemuk [2] dan [3]. Penggunaan menir kedelai sebelumnya dilakukan proteksi agar supaya protein tidak seluruhnya didegradasi oleh mikrobia rumen. Salah satu bahan yang dapat digunakan untuk memproteksi protein adalah formaldehid [4], melalui serangkaian proses berupa ikatan silang antara gugus aldehid dengan protein yang sekaligus sebagai perangkap bagi nutrien lainnya [5], [6], dan [7]. Proteksi terhadap protein menir kedelai pernah diteliti menggunakan aldehid [8] dan [9]. Bahan pakan lokal menir kedelai terbukti menyediakan nutrien bagi mikrobia secara invitro selama 24 jam [2] dan [10]. Proteksi menir kedelai dan minyak ikan lemuru menggunakan aldehid secara in vitro dihasilkan peningkatan $\mathrm{pH}, \mathrm{NH}_{3}$ dan VFA cairan rumen [2]. Penggunaan formaldehid $37 \%$ sebanyak $1 \%$ bahan kering menir kedelai dalam ransum Domba Ekor Tipis dihasilkan peningkatan konsumsi dan kecernaan bahan kering, bahan organik dan protein [3]. Menir kedelai yang diproteksi dengan formaldehid dengan kadar $37 \%$ dosis $2 \%$ dalam bentuk tepung menir kedelai terproteksi dinamakan dengan konsentrat omega 3-6 [2] dan [3]. Proteksi menggunakan formaldehid pada menir kedelai dalam ransum mampu meningkatkan kadar protein dan asam lemak omega 3 dan 6 serta menurunkan kadar kolesterol daging domba lokal jantan [3]. Namun belum ada hasil penelitian mengenai penggunaan menir kedelai terproteksi dan tanpa proteksi dengan rasio yang berbeda terhadap konsumsi, kecernaan dan efisiensi penggunaan nutrien pakan.

Bedasarkan pertimbangan di atas perlu dilaksanakan penelitian dengan kajian penilaian penggunaan menir kedelai proteksi dan tanpa proteksi dalam pakan penggemukan DEG ditinjau dari aspek konsumsi, kecernaan dan efisiensi penggunaan nutrien.

\section{MATERI DAN METODE}

\section{Waktu dan tempat}

Penelitian dilaksanakan selama 6 bulan. Penelitian ini dilaksanakan di kandang Domba Jatikuwung Farm (uji kecernaan) dan Laboratorium Produksi Ternak, Program Studi Peternakan, Fakultas Pertanian, Universitas Sebelas Maret (uji proksimat pakan dan feses).

\section{Bahan dan alat}

Domba Ekor Gemuk (DEG) jantan sebanyak 15 ekor dan dalam keadaan sehat. Berat badan DEG $30 \mathrm{~kg}$, body condition score $(B C S)=3(1-5)$ dan gigi seri sudah tumbuh satu pasang. Menir kedelai diperoleh dari Bantul. 
Formaldehid kadar 37\%. Seperangkat timbangan Domba dan pakan. Seperangkat alat pengujian proksimat.

\section{Jalan penelitian}

Kebutuhan bahan kering penggemukan diberikan 3-4\% dari berat badan DEG. Komposisi pakan pakan perlakuan adalah $30 \%$ rumput gajah, $55 \%$ konsentrat basal, dan $15 \%$ konsentrat perlakuan mengandung menir kedelai proteksi dan tanpa proteksi. Konsentrat perlakuan terdiri dari tiga rasio menir kedelai proteksi dan tanpa proteksi sebesar 75\%:25\%, 50\%:50\%, dan 25\%:75\%. Konsentrat basal terdiri dari 15\% dedak, 15\% pollard, $10 \%$ kulit kopi, $11 \%$ bungkil sawit dan $1 \%$ mineral. Domba ditempatkan di kandang individu ukuran 1,25x0,5x1 m di komplek perkandangan Domba Jatikuwung Farm, Prodi Peternakan FP UNS. Proses pembuatan proteksi menir kedelai adalah menir kedelai dijemur, setelah kering digiling sampai berbentuk tepung, formaldehid kadar $37 \%$ dicampur dengan air perbandingan $1: 10$ kemudian dimasukkan ke dalam mesin pencampur (mixer) dan disemprotkan dengan formaldehid, menir kedelai terproteksi formaldehid ini diperam selama 24 jam, dan sebelum digunakan dianginkan selama 24 jam.

\section{Rancangan percobaan}

Percobaan menggunakan Rancangan Acak Lengkap 3 perlakuan dengan ulangan 5 kali masing- masing ulangan 1 ekor DEG dan uji lanjut duncan multiple range test jika ratarata menunjukkan perbedaan nyata.

\section{Perlakuan}

Pakan perlakuan terdiri 3 perlakuan dapat dilihat pada Tabel 1 di bawah ini. Ketiga pakan perlakuan dibuat iso nutrien mengandung protein kasar 13,02\%, lemak kasar 6,21\%, serat kasar 22,88\%, abu $11,79 \%$,
BETN, 46,05\%, bahan kering 89\%, bahan organik $85 \%$ dan TDN 65\%.

\section{Cara pengumpulan data dan parameter}

Data kecernaan diambil selama 12 hari pada minggu ke-10 dari 12 minggu pemberian pakan. Data dikumpulkan dari hasil pengamatan dan pengujian berbagai variable meliputi:

a. Konsumsi (bahan kering, bahan organik, protein kasar)

b. Kecernaan (bahan kering, bahan organik, protein kasar)

c. Efisiensi penggunaan pakan (bahan kering dapat dicerna, bahan organik dapat dicerna dan protein kasar dapat dicerna).

\section{HASIL DAN PEMBAHASAN}

Hasil penelitian perbedaan rasio menir kedelai terproteksi formaldehid dan tanpa proteksi dapat dilihat pada Tabel 2. Hasil penelitian menunjukan bahwa perbedaan perlakuan berpengaruh nyata terhadap konsumi protein kasar, kecernaan protein kasar dan protein kasar dapat dicerna $(P>0,05)$ dan tidak berpengaruh terhadap konsumsi dan kecernaan bahan kering dan bahan organik serta bahan kering dan bahan organik tercerna $(\mathrm{P}<0,05)$.

Palatabilitas merupakan faktor utama yang mempengaruhi perbedaan konsumsi bahan kering, bahan organik dan PK. Konsumsi PK sangat erat kaitannya dengan konsumsi bahan kering sehingga pada penelitian ini. Hasil penelitian menunjukan tidak adanya pengaruh terhadap konsumsi bahan organik pada penggunaan menir kedelai terproteksi. Konsumsi bahan organik dan konsumsi bahan kering menunjukkan hasil yang sama. Konsumsi bahan organik pakan dipengaruhi oleh total konsumsi bahan kering karena nutrien yang dikandung bahan organik juga terkandung dalam bahan kering.

Tabel 1. Pakan perlakuan penelitian

\begin{tabular}{lccc}
\hline \multirow{2}{*}{ Pakan } & \multicolumn{3}{c}{ Perlakuan } \\
\cline { 2 - 4 } & P1 (\%) & P2 (\%) & P3 (\%) \\
\hline Rumput gajah (RG) & 30 & 30,0 & 30 \\
Konsentrat basal (KB) & 55 & 55,0 & 55 \\
Menir kedelai tanpa terproteksi (MKTP) & 10 & 7,5 & 5 \\
Menir kedelai proteksi (MKP) & 5 & 7,5 & 10 \\
\hline
\end{tabular}


Dalam penelitian ini nampak bahwa menurunnya kecernaan bahan kering dikarenakan daya proteksi sehingga mikrobia dan enzim pencernaan rumen kurang mampu mecerna bahan kering selama dalam rumen. Tidak ada pengaruh negatif dari penggunaan formaldehida di dalam ransum terhadap konsumsi, dan kecernaan bahan kering [11]. Kecernaan bahan organik berbanding lurus dengan kecernaan bahan kering karena bahan organik merupakan bahan penyusun dari bahan kering [12]. Pakan dengan kandungan protein yang cukup menyediakan nitrogen seperti $\mathrm{NH}_{3}$ untuk mikroorganisme dan sumber energi yang juga cukup bagi mikroba rumen akan membantu pencernaan bahan organik sehingga berjalan normal [13] dan [14].

Konsumsi protein kasar P3 lebih tinggi $50,18 \%$ dan kecernaan lebih tinggi 6,64\% dari pada P1. Konsumsi protein kasar P3 penelitian ini di bawah konsumsi protein kasar menir kedelai proteksi $10 \%$ pada ransum Domba Ekor Tipis sebesar 788,67 g/ekor/hari [3], dan pada penelitian sebelumnyaa menggunakan pakan yang sama untuk Kambing Bligon sebesar 89,79 g/ekor/hari [2]. Hal ini menunjukkan bahwa pakan P3 efisien digunakan untuk DEG. Faktor yang mempengaruhi konsumsi protein adalah palatabilitas yang dicerminkan oleh bentuk pakan, bau, rasa dan keadaan fisik yang menumbuhkan daya tarik dan merangsang ternak untuk mengkonsumsinya [15] dan [16].

Kecernaan protein perlakuan P3 sebesar $77,13 \%$ nyata lebih tinggi $6,64 \%$ kecernaan protein kasar dari pada P1 sebesar $72,33 \%$. Hal ini menunjukkan bahwa protein kasar dari ransum yang dikonsumsi dapat dicerna di dalam saluran pencernaan DEG ini efisien. Kecernaan yang tinggi mencerminkan besarnya sumbangan nutrien tertentu pada ternak, sementara itu pakan yang mempunyai kecernaan rendah menunjukkan bahwa pakan tersebut kurang mampu mensuplai nutrien untuk hidup pokok maupun untuk tujuan produksi ternak [17]. Protein yang terproteksi tidak mampu terdegradasi di dalam rumen secara keseluruhan [9]. Protein yang terdegradasi oleh mikrobia rumen menjadi amonia dimanfaatkan bakteri sebagai sumber makanan yang selanjutnya akan diserap usus halus dan di manfaatkan oleh ternak untuk proses metabolisme, sementara protein yang tidak terdegradasi akan langsung masuk ke dalam usus halus [18]. Konsentrasi amonia dalam cairan rumen bergantung pada protein yang tercerna dan kualitas protein pakan [19]. Hasil penelitian yang dilakukan oleh [2] konsentrasi $\mathrm{NH}_{3}$ pada pakan tepung ikan, menir kedelai, dan bungkil kelapa sawit terproteksi menunjukkan hasil yang tidak nyata. Biosintesis protein mikroba mencapai puncaknya pada konsentrasi amonia dalam cairan rumen sekitar $10 \%$ dan kelebihan amonia mencapai $98,3 \%$ tidak lagi

Tabel 2. Penampilan evaluasi pakan mengandung menir kedelai tanpa proteksi dan terproteksi formaldehid untuk penggemukan Domba Ekor Gemuk

\begin{tabular}{lccc}
\hline \multirow{2}{*}{\multicolumn{1}{c}{ Parameter yang diamati }} & \multicolumn{3}{c}{ Perlakuan } \\
\cline { 2 - 4 } & $1.255,4 \pm 26,5$ & $1.283,6 \pm 63,6$ & $1.308,1 \pm 36,6$ \\
\hline Konsumsi Bahan Kering (g/ekor/hari) & $1.007,9 \pm 6,4$ & $1.065,9 \pm 18,3$ & $1.118,7 \pm 27,6$ \\
Konsumsi Bahan Organik (g/ekor/hari) & $128,9 \pm 3,3^{\mathrm{a}}$ & $138,2 \pm 3,7^{\mathrm{a}}$ & $193,6 \pm 7,1^{\mathrm{b}}$ \\
Konsumsi Protein Kasar (g/ekor/hari) & $63,1 \pm 0,5$ & $64,4 \pm 0,5$ & $65,7 \pm 0,5$ \\
Kecernaan Bahan Kering (\%) & $68,3 \pm 0,5$ & $68,9 \pm 0,6$ & $69,4 \pm 0,5$ \\
Kecernaan Bahan Organik (\%) & $72,3 \pm 0,4^{\mathrm{a}}$ & $75,1 \pm 1,1^{\mathrm{b}}$ & $77,1 \pm 0,5^{\mathrm{b}}$ \\
Kecernaan Protein Kasar (\%) & $55,5 \pm 0,6$ & $56,7 \pm 0,3$ & $58,7 \pm 0,3$ \\
Bahan Kering dapat dicerna (\%) & $57,8 \pm 0,3$ & $57,8 \pm 0,3$ & $58,9 \pm 0,6$ \\
Bahan Organic dapat dicerna (\%) & $7,1 \pm 0,0^{\mathrm{a}}$ & $7,4 \pm 0,0^{\mathrm{b}}$ & $7,6 \pm 0,0^{\mathrm{b}}$ \\
\hline Protein Kasar dapat dicerna (\%) & & &
\end{tabular}

Keterangan: a,b,c superskrip yang berbeda pada baris yang sama menunjukkan perbedaan yang nyata $(\mathrm{P}<0,05)$, ns $($ non signifant $)=$ berbeda tidak nyata $(\mathrm{P}>0,05) . \mathrm{P} 1=30 \%$ rumput gajah $+55 \%$ konsentrat basal $+10 \%$ menir kedelai tanpa terproteksi $+5 \%$ menir kedelai proteksi, $\mathrm{P} 2=30 \%$ rumput gajah $+55 \%$ konsentrat basal $+7,5 \%$ menir kedelai terproteksi $+5 \%$ menir kedelai tanpa proteksi P3 $=30 \%$ rumput gajah $+55 \%$ konsentrat basal $+5 \%$ menir kedelai tanpa terproteksi $+10 \%$ menir kedelai proteksi 
merangsang pertumbuhan mikrobia [2]. Penggunaan proteksi pada kedelai cukup efektif untuk menurunkan degradasi protein di dalam rumen [8]. Proteksi bungkil kedelai dengan $1 \%$ formaldehid terbukti secara signifikan menurunkan degradasi protein di dalam rumen sebesar 6,64\% [2]. Kecernaan protein dalam rumen merupakan proses yang kompleks yang dipengaruhi oleh berbagai faktor seperti kelarutan dan struktur protein [20], aktivitas mikroba proteolitik [16], $\mathrm{pH}$ rumen, akses mikroba terhadap protein [17] dan lama waktu tinggal di dalam rumen[18]. [5] menyatakan bahwa degradasi protein dapat dipengaruhi oleh kondisi lingkungan rumen, laju kecernaan dan lama tinggal pakan dalam rumen. Protein yang dapat dicerna P3 lebih tinggi daripada perlakuan lainnya, hal ini menunjukkan bahwa P3 lebih efisien daripada perlakuan lainnya. Tingginya protein kasar dapat dicerna dihasilkan lebih banyak protein kasar yang mampu dimanfaatkan sebagai nutrien penggemukan DEG. Kecernaan dipengaruhi oleh laju perjalanan makanan dalam saluran pencernaan, bentuk fisik atau ukuran makanan penyusun ransum, komposisi kimiawi ransum dan pengaruh dari perbandingan zat makanan lainnya [3] dan [10]. Peningkatan kadar protein dalam pakan akan meningkatkan laju perkembangbiakan dan populasi mikrobia rumen sehingga kemampuan mencerna pakan menjadi lebih besar [19], Optimalnya kerja mikrobia rumen akan berpengaruh terhadap kecernaan protein kasar [20].

\section{KESIMPULAN}

Pakan P3 untuk penggemukan DEG dihasilkan konsumsi dan kecernaan protein kasar yang lebih tinggi dan efisien dari pada P1.

\section{KONFLIK KEPENTINGAN}

Penyandang dana tidak memiliki peran dalam desain penelitian; dalam pengumpulan, analisis, atau interpretasi data; dalam penulisan naskah, atau dalam keputusan untuk menerbitkan hasilnya.

\section{UCAPAN TERIMA KASIH}

Penelitian ini didanai oleh PNBP Universitas Sebelas Maret 2019 dari skim Penelitian Unggulan Terapan UNS (PUTUNS), bidang unggulan ketahanan dan keamanan pangan tahun pertama dari tiga tahun rencana penelitian. Penulis mengucapkan terima kasih kepada Rektor Universitas Sebelas Maret dan Ketua Lembaga Penelitian dan Pengabdian kepada Masyarakat UNS atas pendanaan penelitian ini.

\section{DAFTAR PUSTAKA}

1. Wibowo, M. S., M. D. Efendi, S. D. Widyawati, Lutojo, J. Riyanto, dan W. P. S. Suprayogi. 2012. Pengaruh Suplementasi Minyak Ikan Lemuru dan Minyak Kelapa Sawit Terproteksi dalam Ransum terhadap Performan dan Kualitas Kimia Daging Domba Lokal Jantan. Tropical Animal Husbandry 1 (1): 67-74.

2. Riyanto, J., Sudibya, and S. J. Anhardhika. 2019a. Influence of Soybean Groats Protected Used in The Consumption and Digestibility of Dry Matter, Organic Matter and Crude Protein on The Bligon Goats IOP Conf. Series: Earth and Environmental Science 372 (2019) 012059.

3. Riyanto, J, and Sudibya. 2018. Evaluation of Feeds Thin-Tailed Sheep Profile with Supplemented Protected and Unprotected Aldehyde. IOP Conference Series: Earth and Environmental Science 102 (1): 012011. Doi: 10.1088 / 1755-1315 / 119/1/012020.

4. Stanton, T. L., F. N. Owens, and K. S. Lusby. 1983. Formaldehyde-treated soybean meal for ruminants winter range grass grazing. J. Anim. Sci, 56: 6-14.

5. Mahadevan, S., R. M. Theather, J. D. Erfle, and F. D. Sauer. 1983. Effect of formaldehyde treatment on soybean meal on rates of protein degradation and microbial protein concentration in bovine rumen. Can. J. Anim. Sci. 63: 181-190.

6. Fiems, L. O., Cottyn, B. G., Boucqué, C. V., and Buysse, F. X. 1987. Effect of formaldehyde-treated soya bean meal and urea in starters on nitrogen quality, degradability in sacco, sheep digestibility 
and calf performance. Anim. Feed Sci. Technol., 16(4): 287-295.

7. Nobar, R. S. 2011. Ruminal dry matter degradation of soybean meal as source of escape protein. African J. Biotech. 10 (41): 8090-8092.

8. Riyanto, J., S D Widyawati, W. P. S. Suprayogi, and A. K. Wati. 2019b. The Use of Saponification of Animal and Vegetable Oils in The Rations on The Physical Quality of Sheep Meat on Bicepsfemoris Muscles IOP Conf. Series: Earth and Environmental Science 372 (2019) 012026.

9. Suhartanto, B., Utomo, R., Kustantinah, Budisatria, I. G. S., Yusiati, L. M., and Widyobroto, B. P. 2014. The effect of formaldehyde inclusion on undegraded protein processing and its supplementation level on complete feed pellet on in vitro rumen microbial activities. Bul. Peternakan, 38(3): 141-149.

10. Palizdar, M. H., H. Sadeghipanah, H. Amanlou, H. R. Mohammadian-Tabrizi, and A. Mirhadi. 2012. Effect of soybean meal coated with fat on in vitro organic matter fermentation and gas production. J. Anim. and Vet. Adv, 11 (2): 171-180.

11. Thatcher, W. W., and C. R. Staples. 2000. Effects of dietary fat supplementation on reproduction in lactating dairy cows. Adv. in Dairy Tech. 12: 213 - 232.

12. Jenkins, T. C., R. J. Wallace, P. J. Motae, and E. E. Mosly. 2008. Board-invited review : Recent advances in biohydrogenation of saturated faty acids within the rumen microbial ecosistem. J. Anim. Sci. 86:397412.

13. Stanton T. L., F. N. Owens, and K. S. Lusby. 1983. Formaldehyde-treated soybean meal for ruminants grazing winter range grass. J. Anim. Sci; 56:6-14.
14. Wonnacott, K. E., W. Y. Kwong, J. Hughes, A. M. Salter, R. G. Lea, P. C. Garnsworthy, and K. D. Sinclair. 2010. Dietary omega-3 and -6 polyunsaturated fatty acids affect the composition and development of sheep granulosa cells, oocytes and embryos. Reproduction 39: 57 - 69.

15. Lourenc, M., E. Ramos-Morales, and R. J. Wallace. 2010. The role of microbes in rumen lipolysis and biohydrogenation and their manipulation. Animal (2010), 4 (7): 1008-1023 \& The Animal Consortium 2010.

16. Oldham, J. D., I. C. Hart, and J. A. Bines. 1982. Formaldehide-treated proteins or dairy cows-effects on blood hormone concentration. Er. J. Nutr. 48: 543-547.

17. Tyagi, N., S. S. Thakur, and S. K. Shelke., 2010. Effect of bypass fat supplementation on productive and reproductive performance in crossbred cows. Trop. Anim. Health Prod. 42: 1749 - 1755.

18. Wallace J. M. W., McCabe A. J., Robson, P. J., Keogh, M. K., Murray, C. A., Kelly, P. M., Marquez-Ruiz, G., McGlynn, H., Gilmore, W. S., and J. J. Strain. 2000. Bioavailability of $n-3$ polyunsaturated fatty acids (PUFA) in foods enriched with microencapsulated fish oil. Annal. of Nut. and Met. 44: 157 162.

19. Santos, J. E. P., T. R. Bilby, W. W. Thatcher, C. R. Staples, and F. T. Silvestre. 2008. Long chain fatty acids of diet as faktors influencing reproduction in cattle. Reprod. in Dom. Anim. 43: 23 - 30.

20. Lopes, C. N. A. B. Scarpa, B. I. Cappellozza, R. F. Cooke, and J. L. M. Vasconcelos. 2009. Effects of rumen-protected polyunsaturated fatty acid supplementation on reproductive performance of Bos indicus beef cows. J. Anim. Sci. 87: 3935 - 3943. 